\title{
LEGISLATIVE ENSURE OF TRANSFER OF COMPETENCIES FOR AIR PROTECTION CARRIED OUT BY A MUNICIPALITY
}

\section{LEGISLATÍVNE ZABEZPEČENIE PRENESENÝCH KOMPETENCIÍ PRI OCHRANE OVZDUŠIA OBCOU}

\author{
Jana ĎURKOVIČOVÁ *
}

\section{Introduction}

In the Slovak legislation, air protection is regulated by a comprehensive set of legal regulations that, following on the Constitution of the Slovak Republic and being based on its articles, further elaborate in detail the principles contained therein in their statutory provisions or in the provisions of their implementing regulations. The basic act governing this area is the Act No. 478/2002 Coll. on air protection amend-

\section{Abstract (EN)}

The Slovak Republic pays close attention to effective care of the whole environment, important component of which is also the air. This is ensured through designated authorities within the competence of the State. Municipality, as the basic unit of territorial self-government, is the subject, which has competencies in the area of air protection and acts as a state administration body. This paper focuses on an analysis of legislative assurance of legal relationships arising during the application of the transferred competencies of the state administration to municipalities. In particular, it focuses on the position of the municipality in matters of transferred state administration and its focus on air protection, municipal competencies in air protection, administrative offenses in the competence of the municipality and their solution. Using the methods of analysis, deduction and grammatical and logical interpretation, the paper attempts to continuously monitor, analyse and organise the competencies of the municipality in the exercise of the transferred competencies in the area of air protection and to analyse their application towards obliged subjects from a legislative point of view. In particular, rigorous monitoring and appropriate repressive measures of the municipality are the most effective instrument for achieving the indispensable responsibility of individuals and collective bodies for the state of the air in the defined area. If a sanction is imposed in case of non-compliance with legal obligations, one of the methods currently required for general prevention in this area of the municipality may be fulfilled. By its consistent application activity, the municipality can make a very significant contribution to maintaining or improving the air quality in the area of its territorial scope.

\section{Keywords (EN)}

municipality, air protection, transferred competence, administrative offense, state administration ing also the Act No. 401/1998 Coll. on charges for air pollution, as amended and later adopted Act No. 137/2010 Coll. on Air, as amended, as basic and necessary prerequisites for the implementation of the legislative regulation of air protection. According to Article 44 of the Constitution of the Slovak Republic, everyone shall have the right to favourable environment and everyone shall have a duty to protect and improve the environment. Although the threat and damage to the environment is, to a certain extent, permitted by the

\begin{abstract}
Slovenská republika dôsledne dbá o účinnú starostlivost' o celé životné prostredie, ktorého dôležitou zložkou je aj ovzdušie, čo zabezpečuje prostredníctvom poverených subjektov v pôsobnosti štátu. Subjektom, ktorý má ustanovené pôsobnosti v oblasti ochrany ovzdušia a koná ako orgán štátnej správy je aj obec, ako základná jednotka územnej samosprávy. Článok sa zameriava na analýzu legislatívneho zabezpečenia právnych vztahov, ktoré vznikajú pri uplatňovaní prenesených kompetencií štátnej správy na obce, ktoré ju vykonávajú v oblasti ochrany ovzdušia. Konkrétne sa zameriava na postavenie obce vo veciach preneseného výkonu štátnej správy a jej zameranie pri ochrane ovzdušia, kompetencie obce pri ochrane ovzdušia, správne delikty v kompetencii obce a ich riešenie. Článok sa metódou analýzy, dedukcie a použitia gramatického a logického výkladu pokúša o kontinuálne monitorovanie, analyzovanie a usporiadanie kompetencií a pôsobností obce pri výkone prenesených kompetencií v oblasti ochrany ovzdušia a o analýzu ich aplikácie voči povinným subjektom z legislatívneho hladiska. Najmä dôsledná kontrola a primerané represívne opatrenia obce sú najefektívnejším nástrojom na dosiahnutie nevyhnutnej zodpovednosti jednotlivcov a aj kolektívnych subjektov za stav ovzdušia vo vymedzenej oblasti. Ak pri nedodržaní zákonných povinností bude uložená sankcia, môže sa naplnit' jeden zo spôsobov, v súčasnosti vyžadovanej generálnej prevencie na tomto úseku pôsobnosti obce. Obec svojou dôslednou aplikačnou činnostou, môže velmi výrazne prispiet' k udržaniu alebo k zlepšeniu stavu ovzdušia v oblasti svojej územnej pôsobnosti.
\end{abstract}

\section{Klưčové slová (SK)}

obec, ochrana ovzdušia, prenesené kompetencie, správny delikt, štátna správa 
Constitution of the Slovak Republic, threatening and damaging of environment and natural resources beyond the limits laid down by a law is not desirable and it is forbidden for everyone directly by the Constitution of the Slovak Republic. State pays close attention to effective care of the whole environment, important component of which is also the air. Since the air is essential for life, it is important not only for all inhabitants but also for all other components of the environment affected by the air. The State also shall care for economical exploitation of natural resources, for ecological balance and for agricultural and forest land. At the constitutional level, agricultural and forest land are defined as non-renewable natural resources and enjoy special protection from the State and society directly under the Constitution of the Slovak Republic. ${ }^{(1)}$ In connection with this protection, the State shall secure protection of determined species of wild plants and wild animals.

According to Act No. 137/2010 Coll. on Air, as amended and the related regulations (Air Act), goal of the State is to keep the air quality in areas with good air quality and improve it in other areas. Good air quality means that the level of air pollution is below the limit and target value. These are therefore two important indicators that determine the permissible level of pollution. The limit value is the level of air pollution determined on the basis of scientific knowledge in order to avoid, prevent or reduce harmful effects on human health or on the environment, which has to be achieved at a given time and should not be exceeded from that time. The target value is the level of air pollution intended to avoid, prevent or reduce harmful effects on human health or on the environment, which has to be achieved at a given time when possible. In the field of air protection, according to the Air Act, emphasis is placed primarily on the achievement of an air quality which, on the basis of current scientific knowledge, will not endanger human health and the environment and its components.

\section{Material and methods}

The aim of air care is to obtain information on air quality to help combat air pollution and adverse impacts on the air. Slovak Republic provides effective care of the whole environment, important component of which is also the air. The State conducts regular monitoring and, in particular, assesses air quality, monitors quantitative and qualitative air quality parameters, interprets data and information on status and air regime throughout its territory. This is ensured through designated authorities within the competence of the State. In the legal system of the Slovak Republic, legal protection of air, as one of the components of the environment, is based on the Constitution of the Slovak Republic and is elaborated both in a legal and sub-legal form. The Act establishes the competence of the state authorities of air protection, while the exercise of the whole state administration in the field of air protection is managed by the Ministry. Also, a municipal-

(1) Article 44, Section 5 Act No. 460/1992 Coll. Constitution of the Slovak Republic, as amended by Constitutional Act No.137/2017 Coll. ity as a basic unit of territorial self-government, is an entity having established competencies in the field of air protection and acts as a state administration body. Own or original competencies are exercised by the municipality within the self-government. As part of the transferred exercise of the state administration to the municipality, the municipality exercises the transferred competencies, which is allowed by the Constitution of the Slovak Republic. This paper is focused on analysis of legislative assurance of legal relationships arising during the application of the transferred competencies of the state administration in the field of air protection to municipalities. The basic acts governing the exercise of the transferred competencies of the municipality in relation to the obligated subjects in the field of air protection are mainly the following: Act No. 478/2002 Coll. on air protection; Act No. 401/1998 Coll. on charges for air pollution; Act No. 137/2010 Coll. on Air, as amended containing wide-scaled regulation of air protection; Act No. 369/1990 Coll. on Municipalities, as amended and Decree of the Ministry of Environment of the Slovak Republic No. 410/2012 Coll. implementing certain provisions of the Air Act. This Decree defines small sources of air pollution, their classification and categorization and defines those which are completely entrusted to the controlling authority of the municipality. Using the methods of analysis, deduction and grammatical and logical interpretation, the paper attempts to continuously monitor, analyse and organise the competencies of the municipality in the exercise of the transferred competencies in the area of air protection and to analyse their application towards obliged subjects from a legislative point of view.

\section{Results and discussion}

The status of the municipality in matters of transferred state administration exercise and its focus on air protection

Air Act encompasses municipalities among the air protection authorities together with the bodies of the state administration of air protection other than the ministry, the inspections, the district offices at the headquarters of the region and the district authorities.

The importance of territorial self-government as a basis for any democratic system is already highlighted by the European Charter of Local Self-Government as an international document containing the principles of local self-government. European Charter of Local Self-Government states that local self-government denotes the right and the ability of local authorities, within the limits of the law, to regulate and manage a substantial share of public affairs under their own responsibility and in the interests of the local population. ${ }^{(2)}$ The principle of local self-government shall be recognised in national legislation, and where practicable in the constitution. ${ }^{(3)}$ The legal status of the municipality in the Slovak Republic is based on the Constitution of the Slovak Republic that states that the basic unit of territorial self-ad-

\footnotetext{
(2) Article 3, European Charter of Local Self-Government

(3) Article 3, European Charter of Local Self-Government
} 
ministration shall be the municipality. ${ }^{(4)}$

A municipality and a higher territorial unit are independent territorial and administrative units of the Slovak Republic, associating individuals permanently residing therein. ${ }^{(5)}$

The exercise of the certain powers of local self-administration may be delegated on municipality and higher territorial unit by a law. The costs of the delegated exercise of state administration shall be covered by the State. ${ }^{(6)}$ Where powers are delegated to them by a central or regional authority, local authorities shall, insofar as possible, be allowed discretion in adapting their exercise to local conditions. ${ }^{(7)}$

According to Act No. 369/1990 Coll. on Municipalities, as amended, the extent of the competencies of the municipality, its scope, rights and obligations in relation to air protection is given by the extent of the relationship between the municipality and the State, which may, as already mentioned, delegate certain tasks of the state administration to the municipalities if their fulfilment in this way is more rational and efficient. Together with the transfer of tasks to the municipality, the State will also provide the municipality with the necessary financial and other material resources. The transition of competencies is defined as the transfer of the exercise of the powers of the state administration to the municipalities and self-governing regions and the transfer of powers to the extent specified by the law from the state administration bodies to the self-governing competence of municipalities and self-governing regions. ${ }^{(8)}$ The importance of transferring the exercise of a part of the state administration to the municipality lies above all in accelerating and simplifying the exercise of public administration. When fulfilling tasks within the transferred competence, the territorial self-governing units necessarily cooperate with the state authorities. The legislator, through the transfer of exercise of certain tasks of the state administration to the municipality, thus highlights its position in the system of providing the needs of the State and on the other hand, it requires from the municipalities to carry out properly and timely the tasks transferred.( ${ }^{(9)}$ Should the municipality for a period of at least six months have not exercised its competence during the exercise of the state administration and did not take any measures to secure its exercise at that time, the District Office will ask it in writing for a remedy and determine the time limit for this remedy. If the municipality fails to provide remedy within the stipulated period, the local authority is authorized to act according to a special regulation and the municipality is obliged to pay to the designated local government authority funds for the state

(4) Article 64, Act No. 460/1992 Coll., Constitution of the SR, as amended by constitutional acts

(5) Article 64a, Act No. 460/1992 Coll., Constitution of the SR, as amended by constitutional acts

(6) Article 71, Section 1, Act No. 460/1992 Coll., Constitution of the $\mathrm{SR}$, as amended by constitutional acts

(7) Article 4, European Charter of Local Self-Government

(8) § 1, Section 1, Act No. 416/2001 Coll. on the transfer of certain competencies from state administration bodies to municipalities and higher territorial units, as amended

(9) PALÚŠ, I.- SOMOROVÁ, L. 2010. Štátne právo Slovenskej republiky. Košice. Univerzita Pavla Jozefa Šafárika, 2010. 3. vyd. 558 s. ISBN 9788070977873. administration carried out because of its inactivity.

When exercising the state administration, the municipality may adopt generally binding regulations within its territorial jurisdiction, on the basis of a mandate in the law and within its limits. This power is based directly on the Constitution of the Slovak Republic. In matters in which the municipality exercises the tasks of the state administration, it may adopt such regulations only on the basis of a power of attorney and within its limits.

The regulation must not be in conflict with the Constitution of the Slovak Republic, constitutional laws, international treaties that have been ratified and proclaimed in the manner prescribed by law, laws, government regulations, generally binding regulations of ministries and other central government bodies. ${ }^{(10)}$

Within the meaning of the Act on Municipalities, the municipality is governed by and acts under the laws and other generally binding legal regulations in the matters of the transfer of the state administration in the area of air protection; in other cases, it is also governed by government resolutions and internal normative acts of ministries and other central government bodies.

Exercise of state administration transferred to a municipality or to a higher territorial unit by a law shall be directed and controlled by the government. ${ }^{(11)}$ The application of the principle of supervision is already implemented by the European Charter of Local Self-Government, which states that administrative supervision may be exercised with regard to expediency by higher-level authorities in respect of tasks the execution of which is delegated to local authorities. Administrative supervision of local authorities shall be exercised in such a way as to ensure that the intervention of the controlling authority is kept in proportion to the importance of the interests, which it is intended to protect. ${ }^{(12)}$

In the transferred competencies of the state administration to the municipalities, the controlling responsibility is entrusted specifically to the Government Office of the Slovak Republic, which applies to the bodies of territorial self-government in fulfilling the tasks of the state administration. ${ }^{(13)}$

In accordance with the law, the Government Office, acting on the basis of a governmental decision, controls inter alia the use and efficiency of the state budget resources intended to fulfil the tasks related to the exercise of state administration and its efficiency. The efficiency of state administration is currently an important phenomenon, representing, in terms of law, fulfilment of tasks related to this exercise at the required level, scale and quality, in relation to the available resources of the state budget allocated to the fulfilment of these tasks, to material resources and human resources, while minimizing of resources does not occur at the expense of the quality of fulfilment of the tasks. The necessity of the transfer of competencies from the state administration to the

(10) § 6, Section 2, Act No. 369/1990 Coll. on Municipalities, as amended

(11) Article 71, Section 2, Act No. 460/1992 Coll., Constitution of the $\mathrm{SR}$, as amended by constitutional acts

(12) Article 8, European Charter of Local Self-Government

(13) § 5, Act No. 10/1996 Coll. on control in state administration, as amended 
self-government and the effective allocation of public resources is a part of the reform process of public administration in Slovakia since 2001, when the Act No. 416/2001 Coll. on the transfer of certain competencies from state administration bodies to municipalities and higher territorial units, as amended has been adopted. ${ }^{(14)}$

Control of the efficiency of the state administration is an activity, by which is identified the state and the level of fulfilment of the tasks related to the state administration, the state of utilization of the available resources of the state budget allocated for the fulfilment of these tasks, material resources and human resources, including control of the method of state administration. ${ }^{(15)}$ Regarding the relationship between the Government Office of the Slovak Republic and the municipality in the exercise of the state administration in the area of air protection, the Government Office may provide expert assistance in the field of control to the municipality upon request. However, the control authority of the Government Office does not only apply only to the municipality in fulfilling the tasks of the state administration, but also to the central and local government authorities, as well as their subordinate bodies. The Government Office coordinates and cooperates with ministries and other central state administration bodies as well as with other state administration bodies and legal entities while carrying out its control activities. ${ }^{(16)}$

The state administration of air care is carried out by municipalities to the extent stipulated by a special regulation, which is also the already mentioned Act No. 478/2002 Coll. on air protection amending also the Act No. 401/1998 Coll. on charges for air pollution. Wide-scaled regulation of air protection can be found in the Act No. 137/2010 Coll. on Air, as amended, to the text of which were reflected the repealed or amended provisions of the abovementioned Act No. 478/2002 Coll. on air protection. This global Air Act defines inter alia sources of air pollution that are divided into stationary sources and mobile sources of pollution.

Stationary source is defined as a sum of all facilities and activities within a functional unit and a spatial unit. It may be a technological unit, a warehouse or a landfill of fuels, raw materials and products, a landfill, a quarry or any other area with the possibility of steaming, burning or drifting of pollutants or other construction, object, facility and activity that pollutes or can pollute the air. Mobile source is a mobile device with an internal combustion engine or other engine that pollutes the air. According to law, stationary sources are categorized by the nature of the technological process, technological principle or purpose of the technology according to the established categorization. Within this categorization, depending on the extent of their impact on the air or the extent of the air pollution, they are grouped into large, medium and small sources of air pollution. When implementing the

(14) MARIŠOVÁ, E. et al. 2013. Ongoing reforms in public administration in Slovakia: How effective is the current one envisaged? In: Gazdaság \& Társadalom Journal of Economy \&Society, vol. No.1, pp. 83-98. ISSN 08657823.

(15) \& 2a, Act No. 10/1996 Coll. on control in state administration, as amended.

(16) ŠKULTÉTY, P. 2011. Verejná správa a správne právo. Bratislava: Veda, 2011. 142 p. ISBN 978-80-224-1203. air protection, the municipality is equipped with comprehensive competencies given by law, which focus entirely on small sources of air pollution.

A small source of air pollution is defined by law as the other technological unit, i.e. a technological unit not classified as a major or a particularly important technological unit. Most often, it may be areas where the works that can cause air pollution is carried out, landfills of raw materials and wastes, buildings, installations and air-polluting activities if they are not a part of a large or medium source of pollution.

Decree of the Ministry of Environment of the Slovak Republic No. 410/2012 Coll. implementing certain provisions of the Air Act is an important implementing regulation to this Act, as it establishes small sources of air pollution, their classification, categorization, substantial changes, and defines and divides the equipment of stationary sources.

According to law, the threshold capacity according to the extent of air pollution decides on the inclusion of a stationary source into a category of small sources of pollution. The categorization of stationary resources is outlined in Annex no. 1 of this Decree in a highly sophisticated way. Technology with a capacity smaller than the threshold capacity for medium sources is included as a small source. These are technological units that do not belong to the category of large and medium resources, areas where the works that can cause air pollution is carried out, landfills of raw materials and wastes, buildings, installations and air-polluting activities if they are not a part of a large or medium source of pollution. Examples of typical small sources of air pollution in municipalities include energy sources up to $300 \mathrm{~kW}$, stationary combustion equipment (fireplaces, furnaces, gas boilers), municipal waste water treatment plants, landfills of raw materials, products and wastes, wood processing facilities, factory farming of pigs, poultry, cattle and sheep. In case of doubt about the definition of a stationary source, the classification of the stationary source for its category and the division of the stationary source device, the district office decides according to the law.

\section{Competencies of a municipality in the air protection}

The necessary primary competencies of a municipality in the field of air protection are based on Act No. 401/1998 Coll. on charges for air pollution, as amended, and concern operators of small air pollution sources. The air pollution fee obligation applies to those entities operating small sources of air pollution under the conditions laid down in the law and to such legal and natural persons, who are authorised to do business and are entrepreneurs according to the law. ${ }^{(17)}$ This fee does not apply to operators of small air pollution sources who are not entrepreneurs within the meaning of the aforementioned act, but such operators are subject to the notification obligation according to the law.

The fee charged by a legal person and a natural person entitled to do a business, who operates a small source of air pollution, shall be decided by the municipality within

\footnotetext{
(17) \& 2, Section 2, Act No. 513/1991 Coll., Commercial Code, as amended
} 
the transferred exercise of the state administration. ${ }^{(18)}$ The amount of the charge depends on the review and evaluation of all the essential data that the small air pollution sources operators are obliged to notify to the municipality by law and the amount of the charge that they may affect. A small source operator is required to notify annually (by 15 February of the calendar year) to the municipality for each small source of air pollution the consumption of its fuels and raw materials from which pollutants are generated and other data necessary to detect the amount and harmfulness of pollutants released into the atmosphere during the previous year. These are, in particular, decisive data on the type and qualitative indicators of fuels and raw materials, the number of operating hours of a small source of air pollution and data on type and efficiency of the separation facilities. The municipality itself is entitled by law to lay down all the details of this notice and is entitled to require further details on the charges of a small source operator, as long as the mentioned facts are regulated by a generally binding regulation.

By generally binding regulation, the municipality may, in accordance with the law, also regulate the allocation of those small sources of air pollution in the municipality, which will not charge the fee and may also decide for operators whose small sources of air pollution are not subject to the notification obligation according to the law. In this way, the municipality may exempt small and medium air pollution sources, which are located in dwellings or family houses, in objects and buildings for individual recreation, provided that these resources are not used for business purposes. Small air pollution sources operated by various charities, church and health organizations, as well as entities of the third sector operating on the territory of the municipality, may also be exempt from this obligation under the approved amendment to the generally binding regulations of the municipality. Excluded from these obligations may also be small sources of air pollution that are operated by school facilities in the municipality and, finally, small pollution sources operated by the municipality itself.

In accordance with the law, the municipality will thoroughly review the information contained in the notification from operators of small air pollution sources subject to a fee or notification obligation, and on the basis of the amount and harmfulness of pollutants released into the air or consumption of fuels and raw materials, adopt a decision determining the annual fee of the operator of a small source of air pollution in the previous year, or the amount and terms of the payment of the fee, as well as other conditions regarding the fee for the operator of the small source.

The fee for a small resource operator is determined for each resource per calendar year by a lump sum up to EUR 663.87. The basis for determining its height is the mandatory data reported by operators of small pollution sources according to which the amount is determined in proportion to the quantity and harmfulness of the pollutants released or to the consumption of the fuels and raw materials from which the pollutants originate. The recipient of the fee paid by the small

(18) $\S 28$ f) Act No. 478/2002 Coll. on air protection, as amended by Act No. 525/2003 Coll. resource operator is the municipality; the fees become the income of the municipal budget.

The fulfilment of the obligations related to the notification and charging of business entities as operators of small sources of air pollution in the municipality is unconditional in order to fulfil the obligation of the municipality in this area of environmental protection and thereby to ensure a certain level of air protection in the municipality. If the entrepreneurs do not comply with the obligations stipulated by the law or a generally binding regulation within the statutory deadline mentioned above, and if they fail to comply with the obligations arising from a municipality decision specifying in particular the amount of the annual fee for the small resource operator, the municipality will impose a fine of up to EUR 663.87 on a small source operator within the transferred exercise of state administration.

The municipality may impose a fine within one year from the date when it became aware of this breach of duty, but no later than three years after the breach of this obligation. The possibility of imposing this fine by the municipality does not apply to the municipality's possibility to impose or not to impose a fine. It applies to determine the statutory period of time in a combination of time, or until at the latest when this obligation of the municipality can be fulfilled. The length of this period, in terms of statutory legal time, is classic, normal length, and for practical application of this sanction does not constitute a major obstacle for the municipality. The fines imposed by the municipality become, in accordance with the law, the municipal budget revenue.

However, it is not only a charge and notifying obligation for entrepreneurs, as operators of small sources of air pollution, and its failure to observe any sanctions, where the municipality carries out the delegated competencies given by the law. According to Act No. 137/2010 Coll. on the air, as amended (hereinafter referred to as the Air Act), municipality has, in particular, the significant control power, i.e. the power to control the observance of all obligations of all operators of small sources of air pollution, and also has the power to impose on the operator of the small source of air pollution remedies if he fails to fulfil the obligations laid down by the Air Act and other generally binding legislation in the field of air protection. It has the power to determine the scope and requirements of keeping the operating records of small resources. Very important competence of the municipality in the area of air protection in the framework of the public administration reform is the issuing of approvals for small sources of air pollution.

This is in particular the consent of the municipality, which is necessary for issuing the decisions to authorise the construction of small resources including their changes and the consent to issue decisions for their use. This consent is issued by the municipality to all operators of small sources of air pollution, regardless of their possible business activities, and this consent is a binding opinion in the sense of the Building Act. ${ }^{(19)}$

Other situations that require municipal approval for small

(19) § 140, Act No. 50/1976 Coll. on territorial planning and building order (Building Act), as amended 
sources of air pollution are: the change of used fuels and raw materials in these sources of air pollution; the change of the technological equipment of these stationary sources; or the change of their use, while the municipality also gives consent to the operation of stationary sources after changes that have been made. The consent of the municipality is also necessary for the installation of technological units belonging to the category of small sources, including their changes and their operation, even if the permitting of these sources of pollution is not subject to construction proceedings. In the matter of issue of all these necessary consents, the municipality can also determine the conditions for the operation of small pollution sources.

If the operation of a small source of pollution, the permit of which is not subject to construction proceedings, will be carried out without the consent of the municipality, then the municipality may order the shutdown of such small source. This represents the strictest sanction in relation to the operators of such small sources of pollution.

The highest power of the municipality is to order either a limitation or a direct cessation of the operation of a small source of pollution. This applies in case of a violation of the legislation for all small sources of air pollution in the municipality. Among the strongest competencies of the municipality, besides the statutory right to impose fines on operators of small sources, is the right to lay down a generally binding regulation for a zone with restrictions on the operation of mobile resources. Very recent is also the latest competence entrusted to municipalities by the latest amendment of the Air Act, ${ }^{(20)}$ which is the competence of the municipality to define the low emission zone on the territory of the municipality or at least on its part by a generally binding regulation. This competence based on statutory regulation provides the possibility for municipalities to define low-emission zones within their territory or at least on its part with restricted operation of low-emission motor vehicles. Definition of such zones is one of the possible and good measures to improve air quality, especially in densely populated cities that the municipality can carry out within the area of its territorial scope. When exercising the transferred state administration in the field of air protection according to the Air Act, the municipality also participates on the elaboration and implementation of the programme established by law and the integrated programme. Measures adopted in the area of air protection are included in the spatial planning. This leads to the necessary interconnection of these two areas of competence and to prospective consideration of the air quality in the municipality in the spatial planning. Pursuant to the Air Act, the programme and the integrated programme determine and include measures to improve air quality in the areas of air quality management in order to achieve good air quality at a given time.

In air quality management areas, where limit values or target values are exceeded, including the relevant margin of tolerance for which the deadline for their completion has already expired, the programme or the integrated programme

\footnotetext{
(20) Act No. 350/2015 Coll. amending the Act No. 137/2010 Coll. on Air, as amended
}

shall determine measurable, verifiable and time-bound measures so that the period in which the values are exceeded is as short as possible. The programmes may also include measures that are applied in action plans, but also specific measures aimed at protecting vulnerable groups of the population, including children.

The elaboration of such programmes of measures is not within the competence of the municipality, but of the District Office at the headquarters of the region, which should proceed to the elaboration of these programmes, especially after negotiating with the municipality, whose participation in the elaboration of these programme measures must be unambiguously secured. The municipality, as a basic unit of territorial self-government exercising competence in the area of air protection over operators of small air pollution sources, recognizes these operators, can identify them, can determine the nature of their sources, the degree of pollution and all the circumstances and particularities of specific situations, interrelationships and relationships. The municipality is best able to assess and evaluate the abovementioned facts and thus help to identify the same risks in the design and implementation of programme measures. Active participation of municipalities in the creation of measures of these programmes can also ensure the participation of the municipal community and the representation of its views on this area and the planned future measures and a certain prosperous penetration of the implementation of self-governing and transferred competencies can be achieved. Other entities involved in the creation of these programmes, which cooperate with the District Office at the headquarters of the regions are: higher territorial unit; (in particular) small pollution sources operators in the municipality; the designated organization and authorities concerned. The development and subsequent implementation of the programme and the integrated programme for air protection is mainly required when a limit value or a target value for a single pollutant in the air is exceeded in a given area or the limit and target values for more than one pollutant is exceeded.

\section{Administrative offenses in the competence of the munici- pality and their solution}

Compliance with laws and respect for the rights of others is the duty not only of all citizens, but of subjects of law at all, not exempting the state, as a legislator, from this duty. The task of leading citizens and all subjects of the right to fulfil their responsibilities in the area of public administration is generally imposed on all the administrative authorities, but the different bodies perform it differentiated within its scope and competence. ${ }^{(21)}$ Nowadays, the liability of natural and legal persons is a necessity in the system of taking liability for the unlawful conduct. The legal regime is also subject to all the activities of the public administration; they are bound by the principle of legality and therefore subject to administrative liability, as one of the types of legal liability for violation of established obligations in this area.

In the context of administrative liability, in addition to

(21) ČERVENÝ, Z. - ŠLAUF, V. 2008. Přestupkové právo - Komentář $\mathrm{k}$ zákonu o přestupcích včetně textu souvisících předpisů k 1.3 . 2008. Praha Linde 2008, ISBN 80-7201-713-3. 
offenses, the administrative offense is, as a rule, unlawful conduct, the features of which are laid down by law and for which the administrative body imposes sanctions provided by the administrative-law standard.

Slovak legislation does not precisely define the administrative offense, but it uses this term. It is not precisely defined for reasons of a large scale and an extraordinary diversity of legal obligations, whose enforcement in the area of public administration is imposed by the threat of sanction or by direct sanction for the administrative offense. Offense, as one of the most common types of administrative offenses, is legally defined. ${ }^{(22)}$ Administrative-legal liability means therefore the liability for administrative offenses. Such liability is a secondary obligation to bear the consequences that arise from a<breach of primary obligations. The law always links committing of administrative offense with the threat of sanction. In practice, the sanction imposed for an administrative offense is similar in nature to a punishment for criminal offenses in a criminal law. The sanctions have both repressive function and a function of individual and general prevention. In the case of sanctions for administrative offenses, the principle of officiality is applied in the sense that the administrative authority is obliged to discuss in principle each administrative offense of which it becomes aware. From the point of view of the competence of the administrative authority, it is of particular importance to act in a timely manner, because the expiration of the inappropriate period from the occurrence of the infringement to the sanction itself will lose the effectiveness of the preventive importance of the sanction. Determining the amount of the fine within the statutory margin is a matter for the discretion of the administrative authority, but this does not mean that the sanction can be imposed at any amount. The discretion in such decisionmaking is also the thought process whereby the competent authority should consider the severity of the infringement in relation to each finding, its consequences, the period of unlawfulness so that the fine imposed not only meets the requirement of repression but also the preventive purpose with the prognosis of future positive behaviour of the person concerned. When imposing a fine, the administrative authority shall take into account the severity, manner and duration of the consequences of the unlawful act. The administrative authorities must deal with the issue of the severity of the administrative offense, the manner in which it has been committed, its consequences and the circumstances in which the administrative offense has occurred. ${ }^{(23)}$

According to the Air Act, small source operators commit administrative offenses if they do not comply with the defined obligations or do not observe the prohibitions and the orders provided by the Air Act. In this context, it should be pointed out that in stationary sources, including small sources of air pollution, only fuels determined by the state administration of air protection or by the administrative authority in integrated environmental permitting may be combusted

(22) § 2, Section 2, Act No. 372/1990 Coll. on Offences, as amended.

(23) Zbierka súdnych rozhodnutí. Zbierka stanovísk Najvyššieho súdu a rozhodnutí súdov Slovenskej republiky 7/2013, Rozsudok Najvyššieho súdu Slovenskej republiky z 30. mája 2011, sp. zn. 2Sžp/16/2011 in accordance with the Air Act. If the fuel is not so determined, only the fuels listed in the device documentation can be combusted. The content of the documentation is conditional and binding for operators of small sources of air pollution because, according to this documentation and in accordance with it, small sources operators are obliged to put them into service and to operate stationary sources. When putting stationary sources in operation and during their operation, operators are obliged to fully respect also the operating conditions determined by the municipality itself. If a municipality or inspection imposes on operators of small sources of air pollution a remedy, they are also required to implement it. Other legal obligations for operators of small pollution sources include the obligation to observe the established technical requirements and the conditions of operation of these stationary sources and to observe the obligation not to exceed the established darkness of smoke. The consent of the municipality is necessary for the installation of technological units belonging to the category of small sources, for their change and operation, even if their authorization is not subject to construction proceedings. Small pollution sources operators must respect and comply with the ban on the use of regulated products ${ }^{(24)}$ in small pollution sources and in activities where organic solvents are used when these products do not meet the established requirements to limit emissions of volatile organic compounds. Regulated products are intended exclusively for use in established activities and in installations where organic solvents are used; the specificity of these products is also expressed by the labelling on the product packaging. All of these explicit obligations, which are laid down by the Air Act and are obligated for all operators of small sources, are controllable by the municipality. If the operator of a small source of pollution violates any of them, the municipality or the inspector will impose a fine between EUR 33 and EUR 3,300.

Operators of small air pollution sources, who are entrepreneurs, ${ }^{(25)}$ besides the abovementioned obligations and prohibitions, are also affected by other obligations laid down by the Air Act. Entrepreneurs, as operators of small sources, are obliged to provide access to their stationary sources both to municipal employees and to inspectors or to those authorities, in accordance with the Air Act, for the purpose of detecting the amount of pollutant, controlling the stationary source and controlling its operation. In connection with this obligation, the necessary supporting documents must be also submitted to them. Entrepreneurs, as small resource operators, have an obligation to keep operational records of stationary sources and have to provide the district office with the specified data. Upon request, they are required to provide these and other data necessary to determine the air quality of the municipality, to other air protection authorities or legal entities that are entrusted by them. Entrepreneurs, as operators of small pollution sources, are even obliged to undergo a review of already determined conditions and requirements for the operation of a stationary

\footnotetext{
(24) § 14, Section 6, Act No. 137/2010 Coll. on Air as amended

(25) \& 2, Section 2, Act No. 513/1991 Coll., Commercial Code, as amended
} 
source and must submit the necessary documentation to the municipality, as the municipality has a right to change its original decision by issuing a new decision. Emission limits, technical requirements and operating conditions for the operation and monitoring of a small source of pollution, which are set out in the municipal lawful consents and decisions, can be examined by the municipality as the competent authority for the protection of the air in the proceedings initiated on its own initiative. This applies to cases where, after the issue of the consent or the decision of the municipality, there has been a change in legislation or a change in the best available technique, which allows a significant reduction in emissions from a stationary source. The municipality can change its decision by issuing a new decision, if the introduction of a new available technology into a stationary source is technically and economically feasible for the operator. Upon the change of the stationary source operator, the rights and obligations specified in the decision or in the approval of the district office and the municipality concerning the permits and conditions of operation of the stationary source shall pass to the new operator of the source.

If the entrepreneurs operating small stationary sources violate the above-mentioned obligations, which address operators of small sources of air pollution within the Air Act explicitly, the municipality or inspection will impose a fine of between EUR 20 and EUR 330. Although the lower and upper limits of the fine thus defined and imposed are lower, in particular the upper limit than the limit of the fine that can be imposed on all operators of small sources, it does not represent any advantage for business entities operating small sources of air pollution; on the contrary, that is particular type of fine, which can only be imposed on them as an entrepreneur.

If, within the statutory time limit of one year from the effective date of the decision to impose a fine, the obligations for which the fine was imposed and the operator failed to comply with the remedy imposed by the municipality or inspection, the municipality or inspection shall impose a fine up to twice the upper limit of statutory penalties and the municipality may order, in addition to limitations, the shutdown of the stationary source. The revenues from fines imposed by the municipality for the above-mentioned administrative offenses are the revenue of the municipal budget.

The municipality may, in accordance with the Air Act, initiate proceedings to impose a fine on the operator of a small source of air pollution within one year from the day when the breach was made, but not later than three years from the date of the breach. In deciding on the amount of the fine, the municipality should take into account the circumstances that have led to the breach, the severity and extent of the breach and the duration of the unlawful situation. Municipality should take into account also the operator of the small source of air pollution as such and its relation to compliance with the laws, the decisions of the municipality and, finally, its relationship to its own unlawful conduct and its consequences.

Although the audit institution and its associated repressive measures are often perceived as controversial in society as a whole, the fact is that, in particular, rigorous control and appropriate repressive measures are the most effective means of achieving the indispensable responsibility of individuals and collective bodies for the state of air in the defined area. The control activity carried out by the municipality on various sections and hence on air protection and the subsequent imposition of sanctions, in particular in the form of fines, can be accepted at a basic level of self-government in the municipality with certain disdain, or even refused or subjected to unjustified criticism. However, the imposition of fines for violation of the Air Act is laid down in the form of a statutory wording as a mandatory obligation of the state authorities of air protection and not exempting the municipalities. The municipality's notable reason for doing so is the fact that all the fines paid go to the municipal budget. Operators of small sources of air pollution must be convinced that the real activity of the municipality, perceived in day-to-day practice, is that a sanction will be imposed if the legal obligations are not observed. This is always one of the methods of general prevention in this area. The municipality, through its rigorous application activity, which it actually performs on the basis of valid and effective legislation and also on the basis of its own generally binding regulations, can make a very significant contribution to the improvement of air quality not only in the area of its territory but also in the entire Slovak Republic. Thanks to its wide-ranging and diversified activity carried out within the transferred competencies as well as in the field of air protection, the municipality can significantly influence the consistent and real enforcement of the legislative provisions adopted.

\section{Conclusion}

In the legal system of the Slovak Republic, legal protection of air, as one of the components of the environment, is based on the Constitution of the Slovak Republic and is elaborated both in a legal and sub-legal form. According to the Air Act, mainly the authorities of the state administration of air protection, but also the municipalities are included among the air protection authorities. The municipality exercises the transferred competencies of the state administration in the area of air protection. Transition of competencies is defined as the transfer of the exercise of the powers of the state administration to the municipalities and self-governing regions and the transfer of powers to the extent specified by the law from the state administration bodies to the self-governing competence of municipalities and self-governing regions. The importance of transferring the exercise of a part of the state administration to the municipality lies above all in accelerating and simplifying the exercise of public administration. The basic acts governing the studied area are: Act No. 478/2002 Coll. on air protection amending the Act No. 401/1998 Coll. on charges for air pollution; Act No. 369/1990 Coll. on Municipalities, as amended; later adopted Act No. 137/2010 Coll. on Air, as amended and Decree of the Ministry of Environment of the Slovak Republic No. 410/2012 Coll. implementing certain provisions of the Air Act and defining small sources of air pollution.

If the municipality for a period of at least six months have not exercised its competence during the exercise of the state 
administration and did not take any measures to secure its exercise at that time, the District Office in the seat of the region will ask it in writing for a remedy and determine the time limit for this remedy.

When exercising the state administration, the municipality may adopt generally binding regulations within its territorial jurisdiction, on the basis of a mandate in the law and within its limits. Exercise of state administration transferred to a municipality by a law shall be directed and controlled by the government. Municipal competencies concerning fees for air protection are based on the Act No. 401/1998 Coll. on charges for air pollution, as amended, and concern those operators of small sources of air pollution, who are entrepreneurs. The fee for a small resource operator is determined for each resource per calendar year by a lump sum up to EUR 663.87. The municipality imposes sanctions for non-compliance with the fee and notification obligation. All obligations that are laid down by the Air Act and obligated for all operators of small sources are controllable by the municipality. If the operator of a small source of pollution violates any of them, the municipality or the inspector will impose a fine between EUR 33 and EUR 3,300. Operators of small air pollution sources, who are entrepreneurs, are affected also by other obligations laid down by the Air Act. The imposition of fines for violation of the Air Act is laid down in the form of a statutory wording as a mandatory obligation of the state authorities of air protection and not exempting the municipalities. Operators of small sources of air pollution must be convinced that a sanction will be imposed if the legal obligations are not observed, what always represents one of the methods of general prevention in this area.

\section{References}

1. Act No. 369/1990 Coll. on Municipalities, as amended

2. Act No. 372/1990 Coll. on Offences, as amended

3. Act No. 513/1991 Coll., Commercial Code, as amended

4. Act no. 460/1992 Coll., Constitution of the Slovak Republic, as amended by Constitutional Act no. 137/2017 Z. z.
5. Act No. 10/1996 Coll. on control in state administration, as amended Act No. 416/2001 Coll. on the transfer of certain competencies from state administration bodies to municipalities and higher territorial units, as amended

6. Act No. 478/2002 Coll. on air protection amending the Act No. 401/1998 Coll. on charges for air pollution (Air Act)

7. Act No. $137 / 2010$ Coll. on Air, as amended

8. Act No. 350/2015 Coll. amending the Act No. 137/2010 Coll. on Air, as amended

9. ČERVENÝ, Z., - ŠLAUF, V. 2008. Přestupkové právo - Komentár̆ k zákonu o přestupcích včetně textu souvisících předpisů k 1.3 . 2008. Praha Linde 2008, ISBN 80-7201-713-3

10. Decree of the Ministry of Environment of the Slovak Republic No. 410/2012 Coll. implementing certain provisions of the Air Act

11. European Charter of Local Self-Government

12. MARIŠOVÁ, E. et al. 2013. Ongoing reforms in public administration in Slovakia: How effective is the current one envisaged? In: Gazdaság \& Társadalom Journal of Economy \& Society, vol. No.l, pp. 83-98. ISSN 08657823.

13. PALÚŠ, I. - SOMOROVÁ, L. 2010. Štátne právo Slovenskej republiky. Košice. Univerzita Pavla Jozefa Šafárika, 2010. 3. vyd. 558 s. ISBN 9788070977873

14. PERDUKOVÁ, V., - KOLOVÁ, S. 2011. Ochrana životného prostredia $\mathrm{v}$ podmienkach územnej samosprávy. Zborník príspevkov z vedeckej konferencie. Univerzita Pavla Jozefa Šafárika v Košiciach. ISBN 978-80-7097-873-3

15. ŠKULTÉTY, P. 2011. Verejná správa a správne právo. Bratislava: Veda, 2011. 142 s. ISBN 978-80-224-1203-2.

16. Zbierka súdnych rozhodnutí. Zbierka stanovísk Najvyššieho súdu a rozhodnutí súdov Slovenskej republiky 7/2013, Rozsudok Najvy̌šsieho súdu Slovenskej republiky z 30. mája 2011, sp. zn. 2Sžp/16/2011

17. Act No. 50/1976 Coll. on territorial planning and building order (Building Act), as amended

Contact address/ Kontaktná adresa

JUDr. Jana Ďurkovičová, PhD.

Department of Law, FESRD,

SUA in Nitra, Trieda A. Hlinku 2, 94976 Nitra

Tel: +421 376415071

e-mail: jana.durkovicova@uniag.sk 